\title{
Peningkatan Kualitas Sinyal 4G Berdasarkan Nilai KPI Dengan Metode Drivetest Cluster Padang
}

\author{
Sri Yusnita ${ }^{1 *}$, Yoga Saputra $^{2}$, Dikky Chandra $^{3}$, Popy Maria $^{4}$ \\ 1234 Jurusan Teknik Elektro, Politeknik Negeri Padang \\ 74.sriyusnita@gmail.com \\ Kampus Politeknik Negeri Padang, Limau Manis Padang
}

\begin{abstract}
Abstrak - Pengukuran kulitas sinyal secara aktual pada jaringan 4G menjadi acuan untuk melakukan peningkatan kualitas sinyal. Pengukuran dilakukan terhadap dua operator yang berbeda pada cluster Padang. Parameter pengukuran yang diambil adalah nilai RSRP, SINR dan throughput sebagai parameter dasar standar KPI (Key Performance Indicator). Pengukuran parameter dasar tersebut dilakukan dengan metoda drivetest menggunakan perangkat Tems Pocket sementara untuk analisis data menggunakan Tems discovery dan Mapinfo Pro. Perencanaan jalur pengambilan data merupakan bagian penting untuk mengetahui bad spot area dua operator tersebut untuk perencanaan peningkatan kualitas sinyal. Hasil pengukuran pada proses collect data untuk kategori buruk dan tidak terdeteksi sama sekali digunakan untuk menentukan posisi new site dengan memeperhatikan ketiga parameter sinyal, jumlah user pada daerah itu, batas minimum radius bad signal serta posisi site yang sudah ada untuk kedua operator. Menggunakan metode silang diperoleh tiga titik koordinat new site yaitu pertama pada longitude $100.403428^{\circ}$ dan latitude $-0.870309^{\circ}$, titik kedua pada longitude $100.3763311^{\circ}$ dan latitude $-0.858726^{\circ}$, serta $^{\circ}$ titik ketiga pada longitude $100.404072^{\circ}$ dan latitude $-\mathbf{0 . 9 6 6 5 0 3}^{\circ}$ serta 47 titik bad spot area.
\end{abstract}

Kata kunci: Drivetest, Tems Pocket, Key Performance Indicator, New site, Bad Spot Area

Abstract-The real signal quality measurement on the $4 G$ network is a reference to improve signal quality. Measurements were made for two different operators on the Padang cluster. The measurement parameters taken are the RSRP value, SINR and throughput as the basic parameters of the KPI (Key Performance Indicator) standard. Measurement of these basic parameters is done by the drive test method using the Tems Pocket device while for data analysis using Tems discovery and Mapinfo Pro. Planning the data collection path is an important part to find out the bad spot areas of the two operators for planning signal quality improvement. The measurement results in the process of collecting data for bad categories and not being detected at all are used to determine the position of the new site by taking into account the three signal parameters, the number of users in the area, the minimum limit of the bad signal radius and the site positions that already exist for both operators. Using the cross method, three new site coordinate points are obtained, namely first at longitude $100.403428^{\circ}$ and latitude $-0.870309^{\circ}$, second point at longitude $100.376331{ }^{\circ}$ and latitude $-0.858726^{\circ}$, and third point at longitude $100.404072^{\circ}$ and latitude $-0.966503{ }^{\circ}$ and 47 bad spot area.

Keywords: Drivetest, Tems Pocket, Key Performance Indicator, New site, Bad Spot Area

(C) 2019 Elektron Jurnal Ilmiah

\section{PENDAHULUAN}

Beberapa masalah yang ditemui dalam layanan jaringan seluler adalah kualitas sinyal yang kurang baik, sinyal yang hilang secara tiba-tiba atau tidak ada jaringan sama sekali. Masalah ini bisa disebabkan alasan teknis maupun non teknis. Untuk mengatasi permasalahan tersebut sudah dilakukan beberapa penelitian seperti [3], [5], [6]. Peningkatan kualitas sinyal dilakukan berdasarkan perkiraan ilmiah dan bergantung pada data posisi BTS (Base Tranceiver Station) yang sudah terpasang, data kapasitas pelanggan, serta data trafik dari tiap-tiap BTS yang sudah ada. Penelitian [5] dan [6] memiliki kesamaan dalam tujuan untuk menghindari pembangunan site baru yang banyak untuk menjaga estetika dan keamanan lingkungan

Berbeda dengan penelitian sebelumnya, pada penelitian ini pengukuaran data aktual dilapangan terhadap jaringan 4G menjadi acuan dalam melakukan analisis untuk meningkatkan kualitas sinyal melalui metoda drive test. Standar KPI (Key Performance
Indicator) merupakan pembanding dalam menentukan kategori sinyal dengan pembedaan warna pada masingmasing parameter. Parameter data yang diambil adalah RSRP (Reference Signal Received Power), SINR (Signal to Noise Ratio) dan throughput. Pengukuran dilakukan terhadap dua jaringan $4 \mathrm{G}$ atau dua operator yang berbeda tetapi pada jalur yang sama.

Proses analisis data untuk peningkatan dan pemerataan kulitas sinyal dilakukan bedasarkan data kualitas sinyal terukur. Kategori kualitas sinyal buruk dan tidak ada sama sekali utuk kedua operator menjadi acuan untuk keputusan bad spot area dan bad spot signal. Kedua kategori ini dibedakan berdasarkan radius kualitas sinyal kategori buruk. Menggunakan metode silang dapat ditentukan jumlah new site yang harus dibangun serta posisi penempatan new site tersebut dengan mempertimbangkan beberapa parameter data pendamping. Metode silang digunakan dengan pertimbangan untuk menghindari dibangunnya site baru secara fisik. 


\section{METODE}

Untuk meningkatkan kualitas sinyal dan pemerataan kualitas sinyal cluster padang melalui pengukuran data aktual maka dilakukan beberapa proses awal diantaranya pengumpulan data berupa data pemetaan wilayah, jumlah calon pengguna jaringan dari BPS (Badan Pusat Statistik) kota padang dan data posisi eNodeB yang sudah terpasang untuk kedua jaringan $4 \mathrm{G}$ yaitu operator $\mathrm{X}$ dan Operator $\mathrm{Y}$.

Tahapan selanjutnya yaitu proses collect data atau pengambilan data kualitas sinyal yang terdiri dari tiga bagian utama berdasarkan gambar 1. Bagian pertama perencanaan jalur untuk pemetaan wilayah dan jumlah user yang berguna untuk mendukung wilayah yang benarbenar membutuhkan perbaikan kulaitas sinyal. Bagian kedua proses collect data menggunakan metoda drive test dengan memperhatikan dua hal yaitu terjaganya koneksi jaringan dan jalur data yang akan diambil untuk menghindari terjadinya error. Bagian ketiga adalah analisis data menggunakan metode silang dari dua operator dengan hasil akhir berupa penentuan jumlah dan posisi new site.

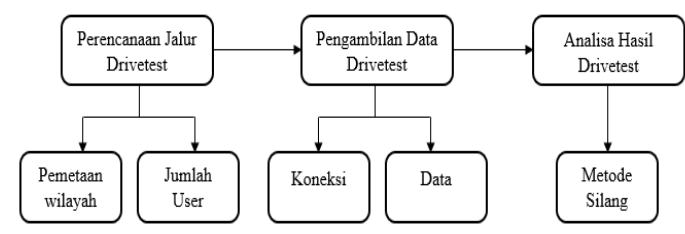

Gambar 1. Blok diagaram metode penelitian

\section{Perencanaan Jalur Drive Test}

Perencanaan jalur drive test sangat dibutuhkan untuk pemetaan cluster terutama untuk mencegah pengulangan pengambilan data dan sebagai panduan dalam melakukan drive test. Perencanaan jalur mengutamakan jalan-jalan protokol seperti jalan Gajah Mada, K.H Ahmad Dahlan, Jhoni Anwar dan Thamrin [9]. Pembuatan jalur drive test ini menggunakan aplikasi Google Earth. Gambar 2 merupakan hasil perencanaan jalur yang akan dilewati untuk proses collect data.

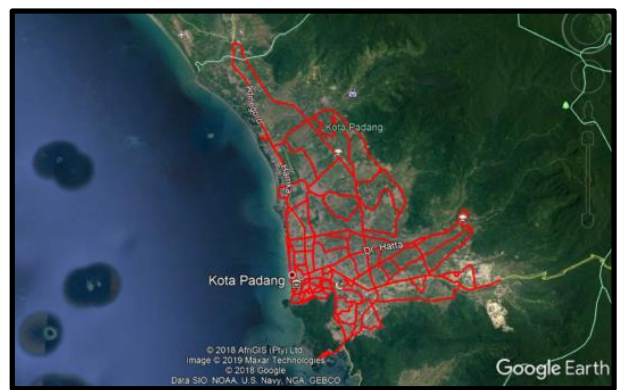

Gambar 2. Tampilan jalur drivetest

\section{Pengambilan Data Drive Test 4G}

Drive test merupakan suatu metode untuk mengukur quality of service (QOS) serta parameter dasar kualitas sinyal secara aktual terhadap radio frequency (RF) suatu eNodeB. Pengukuran dilakukan menggunakan TEMS Pocket versi 15.1 yang terpasang pada perangkat Samsung Galaxy S5 SM-G900I (LTE / WCDMA / GSM) seperti gambar 3. Drivetest dilakukan secara plotting/pinpoint automatic dengan kendaraan roda empat mengikuti jalur yang sudah direncakan.

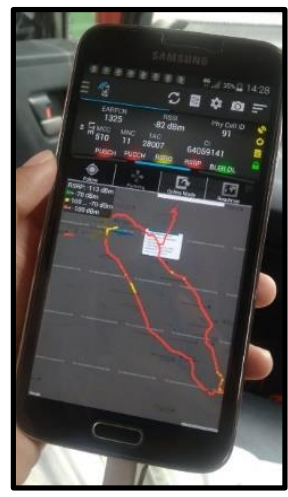

Gambar 3. Tampilan TEMS Pocket

\section{Analisis Hasil Drive Test}

Hasil pengukuran drivetest dalam bentuk logfile dianalisis menggunakan software TEMS Discovery, TEMS Investigation dan Map Info Pro. Analisis data bad signal bertujuan untuk menemukan titik new site kedua operator tersebut. Penggabungan data hasil drive test menggunakan aplikasi Tems Discovery dan untuk menganalisis hasil data drivetest menggunakan aplikasi Mapinfo pro 15. Parameter yang dianalisa adalah nilai RSRP, SINR dan throughput berdasarkan standar KPI (Key Performance Indicator) yang menjadi indikator bagus atau tidaknya performance suatu jaringan.

Terdapat lima indikator warna umum yang digunakan sebagai penentu baik atau buruknya suatu sinyal pada KPI. Yakni purple, blue, green, yellow dan red[4]. Purple menandakan bahwa sinyal tersebut tergolong sangat baik, blue menandakan bahwa sinyal tersebut baik, green menandakan bahwa sinyal tersebut cukup baik, yellow menandakan bahwa sinyal tersebut lemah atau cukup buruk, dan red menandakan bahwa sinyal tersebut sangat buruk.

\section{RSRP (Reference Signal Received Power)}

RSRP didefinisikan sebagai power sinyal referensi yang diterima pada keseluruhan bandwidth. Pengukuran parameter RSRP digunakan untuk menunjukkan coverage dari jaringan LTE karena berperan dalam menentukan titik handover. Tabel 1 menunjukkan range nilai RSRP untuk beberapa kategori sinyal [4].

Tabel 1. Range nilai RSRP (dBm)

\begin{tabular}{lll}
\hline RSRP & Color & Strength $(\mathrm{dBm})$ \\
\hline Excellent & Blue & $-80=<\mathrm{x}$ \\
Good & Green & $-95=<\mathrm{x}<-80$ \\
Low & Yellow & $-110=<\mathrm{x}<-95$ \\
Bad & Red & $\mathrm{X}<-110$ \\
\hline
\end{tabular}

SINR (Signal to Interference and Noise Ratio)

SINR adalah perbandingan power dari sinyal referensi dengan power interferensi (I) dan noise $(\mathrm{N})$ pada subcarrier yang sama ditunjukkan pada persamaan 1 .

$$
S I N R=\frac{R S R P s e r v}{\sum R S R P o t h e r+I+N}
$$


Tabel 2 merupakan contoh standar range SINR untuk beberapa kategori [4].

Tabel 2. Range nilai SINR (dB)

\begin{tabular}{lll}
\hline SINR & Color & Strength $(\mathrm{dB})$ \\
\hline Excellent & Blue & $20=<\mathrm{x}$ \\
Good & Green & $13=<\mathrm{x}<20$ \\
Low & Yellow & $0=<\mathrm{x}<13$ \\
Bad & Red & $\mathrm{X}<0$
\end{tabular}

\section{Throughput}

Throughput berhubungan dengan proses transfer data baik upload maupun download. Berikut range nilai throughput untuk beberapa kategori seperti pada tabel 3 [4].

Tabel 3. Range Throughput

\begin{tabular}{lll}
\hline Throughput & Color & Strength $(\mathrm{kbps})$ \\
\hline Excellent & Purple & $14000=<\mathrm{x}$ \\
Good & Blue & $7000=<\mathrm{x}<14000$ \\
Low & Green & $1000=<\mathrm{x}<7000$ \\
Very Low & Yellow & $512=<\mathrm{x}<1000$ \\
Bad & Red & $\mathrm{X}<512$ \\
\hline
\end{tabular}

\section{HASIL DAN PEMBAHASAN}

\section{Hasil collect data Drive Test}

Setelah melakukan drive test dan menggabungkan hasil logfile menggunakan Tems discovery diperoleh tampilan nilai RSRP, SINR dan throughput untuk jaringan $4 \mathrm{G}$ operator X dan Y seperti ditunjukkan dalam gambar 4, gambar 5 dan gambar 6 .
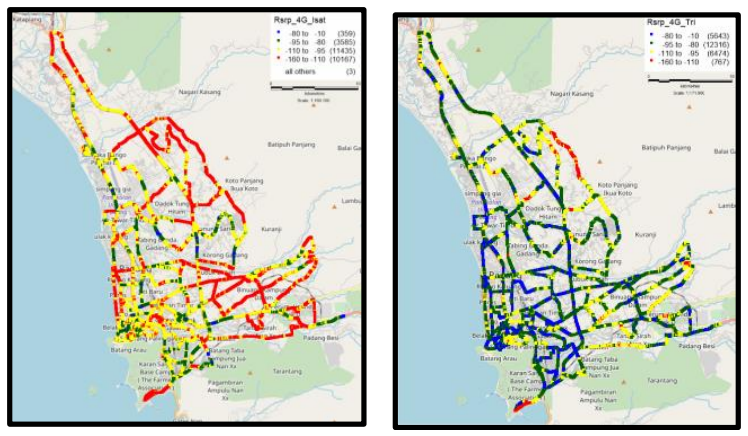

Gambar 4. Hasil drivetest RSRP jaringan X dan Y

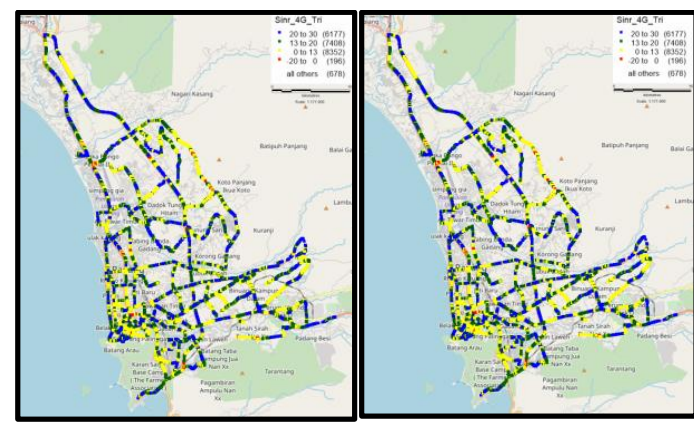

Gambar 5. Hasil drivetest SINR jaringan X dan Y

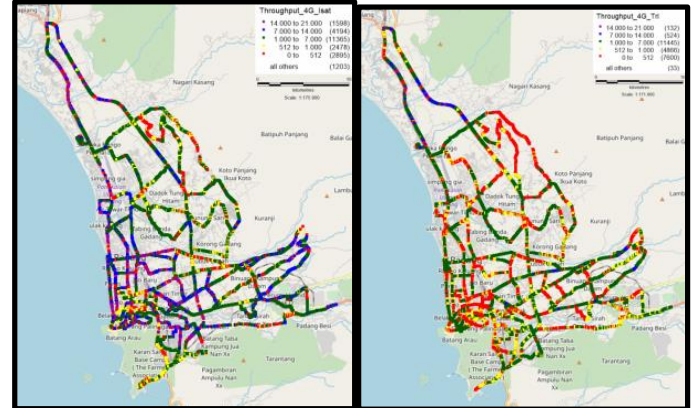

Gambar 6. Hasil drivetest Throuhput jaringan X dan Y

\section{Cakupan Wilayah Bad Signal}

Bagian ini berfungsi untuk menilai suatu wilayah tersebut termasuk dalam kategori bad signal maupun bad spot. Untuk menentukan kategori sinyalnya dilakukan dengan cara membandingkan ketiga parameter jaringan tersebut. Panjang bad spot minimum jarak $2 \mathrm{~km}$ dan jumlah calon user minimum 200 orang [4].

Gambar 7 menunjukkan tampilan wilayah bad signal1 operator X. Nilai rata-rata RSRP, SINR dan Throughput adalah $-118.373267 \mathrm{dBm}, 12.035887 \mathrm{~dB}$, dan 1194.399841 kbps. Dengan panjang bad signal $3.404 \mathrm{~km}$ serta berada pada wilayah sub urban. Pada gambar juga tampak wilayah yang kehilangan sinyal ditandai dengan terputusnya plotting sinyal.

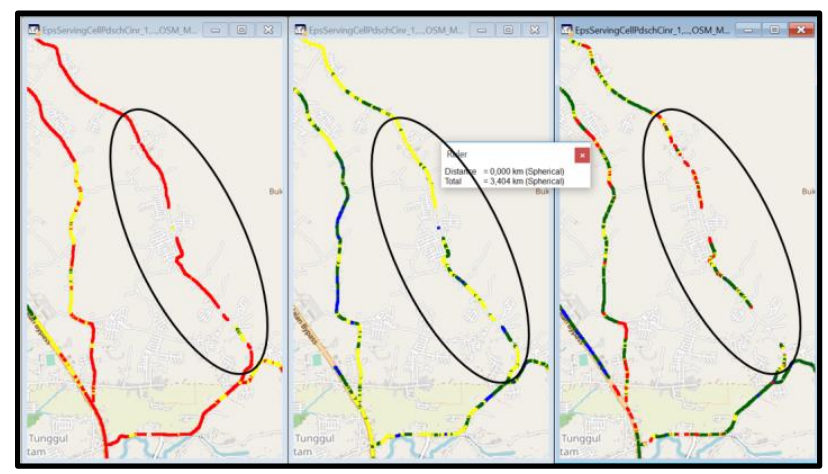

Gambar 7. Tampilan wilayah bad signal-1 operator X

Gambar 8 merupakan tampilan wilayah bad signal-2 operator $\mathrm{X}$ dengan nilai rata-rata RSRP, SINR dan Throughput adalah -114.418814 dBm, $14.114706 \mathrm{~dB}$, dan 638.138639 kbps. Panjang bad signal $2.185 \mathrm{~km}$ serta berada pada wilayah sub urban. Pada gambar tampak banyak wilayah yang memiliki kualitas sinyal buruk

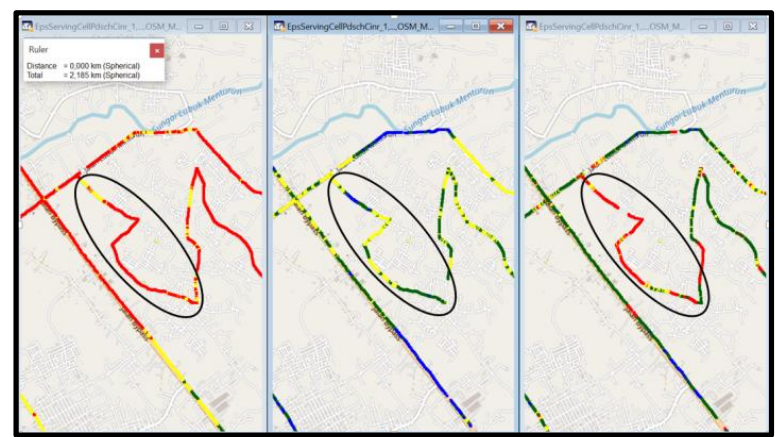

Gambar 8. Tampilan wilayah bad signal-2 operator $\mathrm{X}$ 
Gambar 9 menunjukkan tampilan wilayah bad signal1 operator Y dengan nilai rata-rata RSRP, SINR dan hroughput adalah $-110.385388 \mathrm{dBm}, 6.529234 \mathrm{~dB}$, dan 460.823770 kbps. Panjang bad signal $3.18 \mathrm{~km}$ serta berada pada wilayah sub urban.

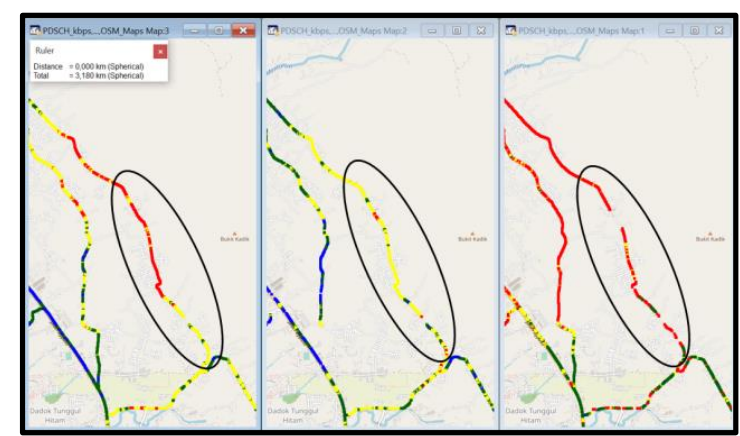

Gambar 9. Tampilan wilayah bad signal-1 operator $\mathrm{Y}$

Tampilan wilayah bad signal-2 operator $Y$ terlihat pada gambar 10. Nilai rata-rata RSRP, SINR dan Throughput adalah $-102.130612 \mathrm{dBm}, 7.027517 \mathrm{~dB}$, dan $596.597584 \mathrm{kbps}$. Panjang bad signal $3.46 \mathrm{~km}$ serta berada pada wilayah sub urban. Pada gambar juga tampak wilayah yang kehilangan sinyal ditandai dengan terputusnya plotting sinyal.

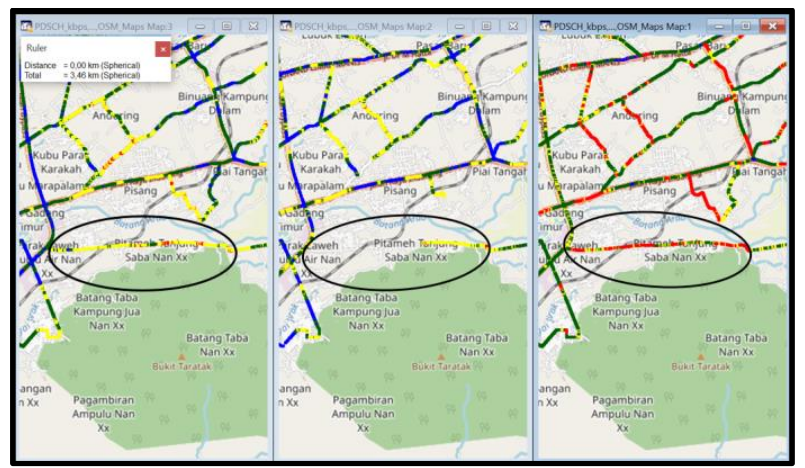

Gambar 10. Tampilan wilayah bad signal-2 operator $\mathrm{Y}$

Jumlah user

Jumlah penduduk per kilometer persegi di seluruh kecamatan di Kota Padang juga menjadi salah satu indikator dalam penentuan new site BTS. Menggunakan citra satelit google map to earth yang menunjukkan permukiman secara real berfungsi untuk meningkatan ketepatan sasaran dalam peningkatan kualitas sinyal secara merata.

Gambar 11 menunjukkan data User dari lokasi bad signal sektor satu operator X kecamatan Koto Tangah. Titik site ditandai dengan pin point berwarna merah yang melingkupi wilayah bad signal tersebut.

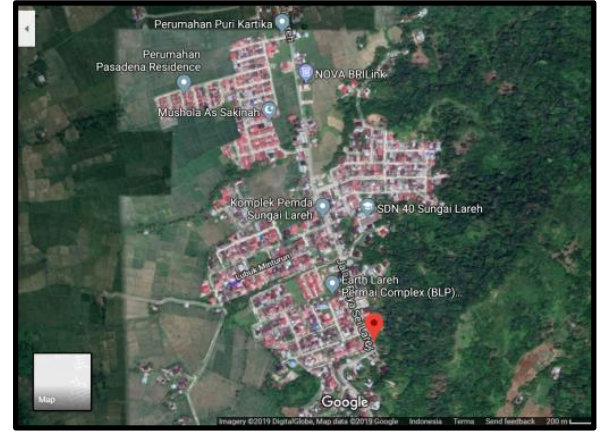

Gambar 11. Tampilan User Operator X-1

Gambar 12 menunjukkan data dari lokasi bad signal sektor dua operator X kecamatan Koto Tangah.

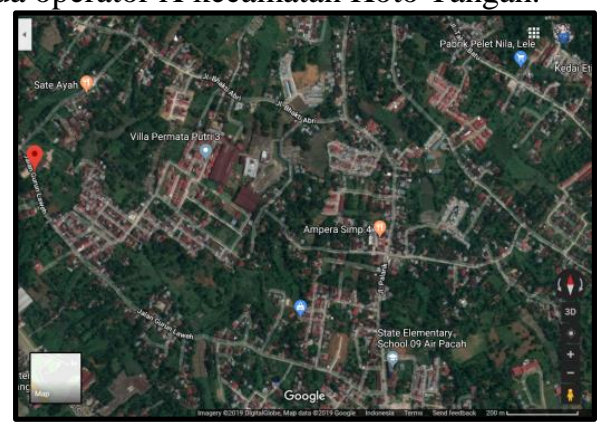

Gambar 12. Tampilan User X-2

Gambar 13 menunjukkan data User lokasi bad signal sektor satu operator Y kecamatan Koto Tangah. Titik site ditandai oleh pin point berwarna merah yang melingkupi wilayah bad signal tersebut. Dari gambar 13 tampak kesamaan posisi bad signal dengan operator $\mathrm{X}$ pada gambar 11.

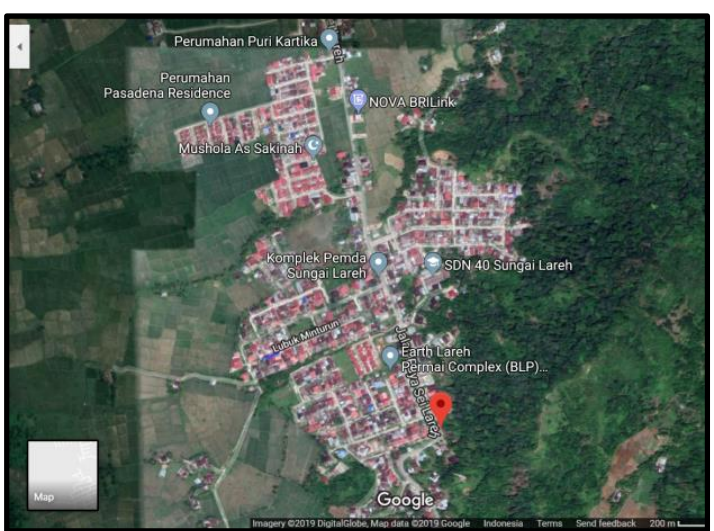

Gambar 13. Tampilan User Y-1

Gambar 14 menunjukkan data User yang diambil menggunakan citra google map to earth dari lokasi bad signal sektor dua Operator Y kecamatan Lubuk Begalung. 


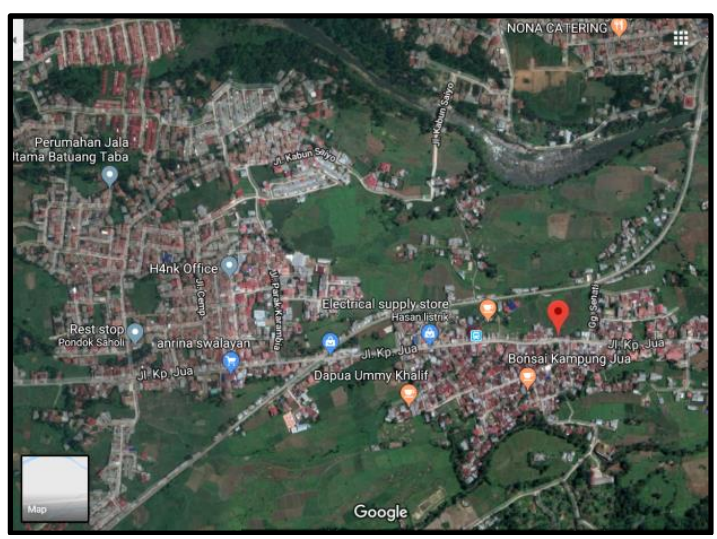

Gambar 14. User Y- 2

\section{Analisis New Site}

Terdapat dua kategori sinyal yakni bad signal dan bad spot area. New site dibangun berdasarkan bad signal dua operator pada titik atau wilayah yang sama. Jika hanya salah satu dari operator yang memiliki sinyal buruk maka operator yang memiliki bad signal pada lokasi tersebut akan ditumpangkan pada site operator yang memiliki sinyal baik pada wilayah atau titik tersebut. Metode penentuan new site dua operator ini disebut dengan metode silang. Data yang dibandingkan adalah nilai parameter RSRP, SINR dan throughput.

Dengan menggunakan indikator KPI parameter tersebut diklasifikasikan menjadi sinyal baik, buruk dan lemah maupun memang tak terdeteksi sinyal sama sekali. Titik sinyal buruk ditentukan apabila ketiga parameter tersebut dalam kondisi buruk, dalam kondisi lemah ataupun memang tidak terdeteksi sinyal sama sekali. Selain bad signal dibutuhkan dua persyaratan lagi untuk penentuan new site yaitu jumlah user dan panjang bad signal itu sendiri. Untuk jarak bad signal menggunakan batas minimum $2 \mathrm{~km}$ dan jumlah User batas minimumnya 200 subscriber [4]. Panjang wilayah bad signal dari keempat titik yang ditemukan memiliki panjang diatas 2 $\mathrm{km}$, maka jumlah user minimum sudah terpenuhi karena kepadatan penduduk $817 \mathrm{~km}^{2}$ dan $3923 \mathrm{~km}^{2}$ pada wilayah tersebu[1].

Berdasarkan empat titik bad signal pada operator X dan $\mathrm{Y}$ terdapat dua titik bad signal yang sama pada gambar 11 dan gambar 13 memungkinkan dibangun titik new site bersama pada wilayah tersebut dengan titik koordinat longitude $100.403428^{\circ}$ dan latitude $0.870309^{\circ}$ ditunjukkan pada gambar 15 .

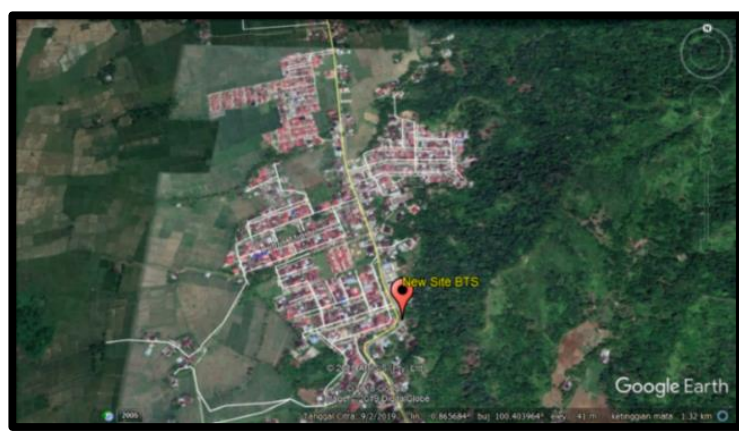

Gambar 15. New site Bersama
Sedangkan untuk dua titik bad signal yang ditunjukkan gambar 12 dan gambar 14 dilakukan proses penumpangan pada BTS terdekat. Dikarenakan salah satu operator memiliki sinyal yang baik sehingga tidak perlu pembangunan new site. Untuk Data 2 bad signal operator X melakukan penumpangan pemancar sinyal pada eNodeB terdekat operator Y dengan koordinat longitude $100.376331^{\circ}$ dan latitude $-0.858726^{\circ}$ yang ditunjukkan pada gambar 16 .

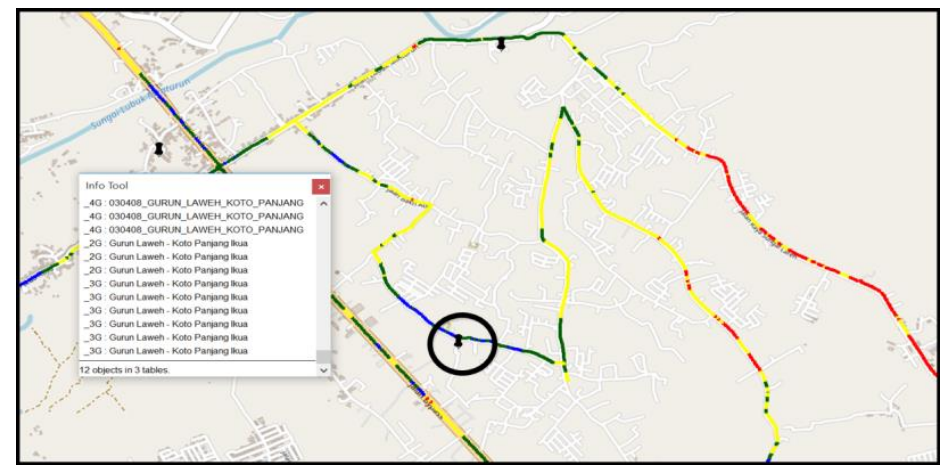

Gambar 16. Koordinat penumpangan pada BTS Y

Bad signal operator $\mathrm{Y}$ juga dilakukan penumpangan pemancar sinyal karena sinyal $\mathrm{X}$ pada wilayah tersebut memiliki sinyal yang baik. Penumpangan pemancar operator $\mathrm{Y}$ dilakukan BTS terdekat $\mathrm{X}$ dengan koordinat longitude $100.404072^{\circ}$ dan latitude $-0.966503^{\circ}$ yang ditunjukkan pada gambar 17.

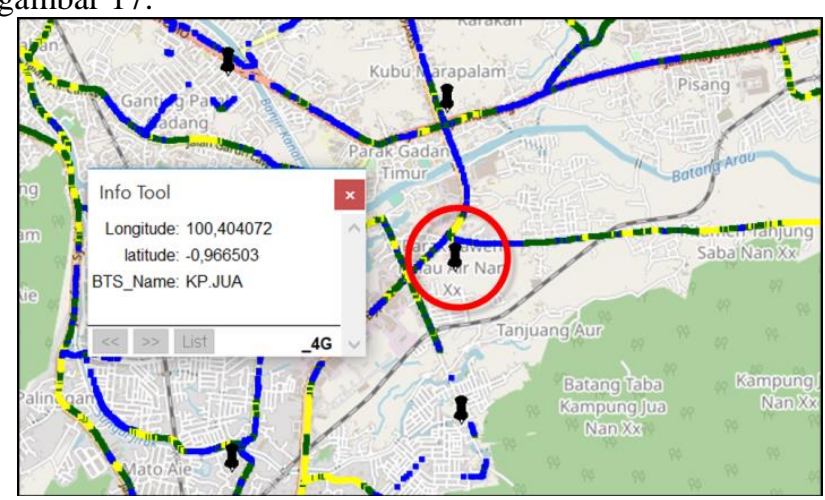

Gambar 17. Koordinat penumpangan pada site $\mathrm{X}$

Dengan menggunakan metode pengambilan data drivetest dan metode analisis silang tersebut dapat mengimplementasikan peraturan Menkominfo tentang pembangunan dan penggunaan bersama menara telekomunikasi dengan memperhatikan keamanan dan estetika lingkungan [5],[6] dengan mengedepankan aspek data secara aktual.

\section{Analisis Bad Spot Area}

Bad spot area adalah wilayah-wilayah yang didapati sebagai wilayah yang memiliki sinyal buruk. Penentuan bad spot area ini berdasarkan parameter RSRP, SINR dan Throughput dengan sinyal pembanding Key Performance Indicator (KPI). Berdasarkan gambar 18 didapatkan 
sebanyak 47 titik bad spot di Kota Padang. Pin point kuning menandai bad spot untuk operator $\mathrm{X}$ dan pin point merah untuk operator Y. Peningkatan kualitasnya cukup dengan melakukan physical tunning pada BTS terdekat dikarenakan wilayah bad spot tersebut tidak memenuhi panjang minimum dilakukannya pembangunan new site BTS [4].

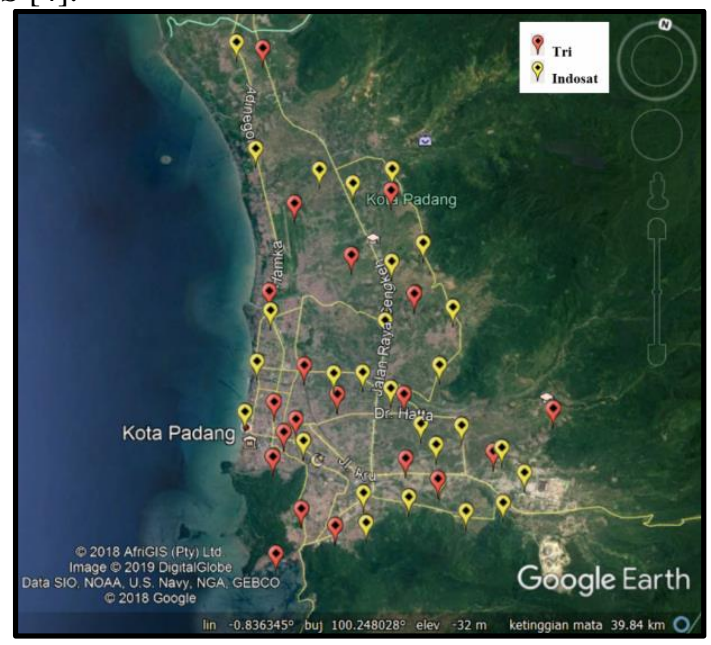

Gambar 18. Tampilan bad spot area operator X dan Y

\section{KESIMPULAN}

Berdasarkan analisis hasil drive test perlu dibangun tiga eNode B untuk meningkatkan kualitas sinyal. . Satu lokasi eNode B berupa new site bersama dua operator X dan Y. Satu site berupa penumpangan site X pada site $\mathrm{Y}$ dan satu site lagi berupa penumpangan site $\mathrm{Y}$ pada site $\mathrm{X}$. Hasil analisis juga memperoleh 47 bad spot area untuk dilakukan physical tunning.

\section{REFERENSI}

[1] BPS (view 28 Mei 2019). Kepadatan Penduduk Menurut Kecamatan Di Kota Padang Tahun 2010-2017 [Online]. Availabel: https://padangkota.bps.go.id/dynamictable/2018/10/31/251/kepadata n-penduduk-menurut-kecamatan-di-kota-padang-tahun-20102017.html.

[2] Efriyendro, R dan Rahayu, Y. Analisa Perbandingan Kuat Sinyal 4G LTE Antara Operator Telkomsel dan XL AXIATA Berdasarkan Paramater Drive Test Menggunakan Software G-NetTrack Pro Di Area Jalan Protokol Panam. Jom FTEKNIK. 4(2). 1-9. 2017.

[3] Hidayah, Nurul. 2017. Optimasi Penentuan Posisi Perencanaan Jaringan LTE E-UTRAN pada Evolved Node B Menggunakan Probabilitas Monte Carlo. Skripsi. Universitas Jember.

[4] Javandra. (view 28 Mei 2019). Drivetest Analyst [Online]. Available : http://www.javandra.com/.

[5] Pitisye, S., et all." Perencanaan Coverage Area Untuk Penempatan E Node-B Optimal Pada BTS Existing 3G Di Kota Padang Menggunakan Metode Particle Swarm Optimization (PSO)". Seminar Nasional Teknologi Informasi, Komunkas dan Industri (SNTIKI-10). 459-466. 2018.

[6] Safitri, R. 2017. Optimasi Penentuan Posisi eNode-B pada BTS 2G/3G yang Terpasang Di Kota Padang Menggunakan Algoritma Genetika. Skripsi. Politeknik Negeri Padang.

[7] Sugiharto A, Alfi, I. "Analisa Performa Jaringan 4G LTE Berbagai Provider Seluler di Area Kota Yogyakarta”. Prosiding Seminar Nasional Unimus. 2018. 589-595. 2018.

[8] Wardhana, L. 2G/3G RF Planning and Optimization for Consultant (plus introduction to $4 G$ ). www.nulisbuku.com. Jakarta Selatan 12780. 2011.

[9] Yunanda, F. (view 28 Mei 2019). Nama Jalan Protokol di Kota Padang [Online]. Available : https://www.infosumbar.net/artikel/nama-jalanprotokol-di-kota-padang/.

[10] X. Zhang, LTE Optimization engineering handbook, first edition, IEEE Pres, Willey, 2018 